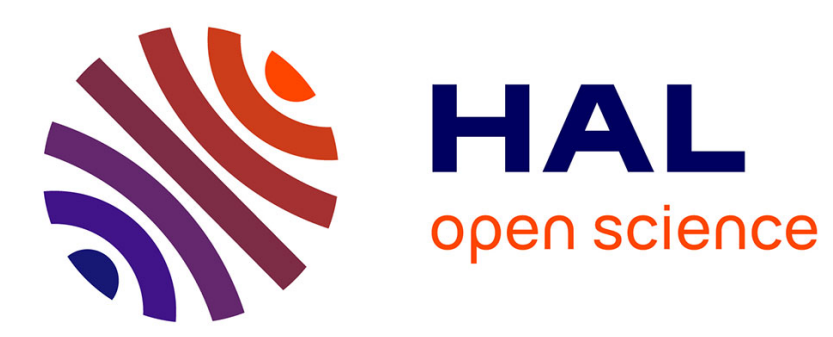

\title{
Mechanism of Biological Fe3O4 Synthesis, in Relation to Ferrite Plating
}

\author{
M. Abe, Y. Tamaura
}

\section{To cite this version:}

M. Abe, Y. Tamaura. Mechanism of Biological Fe3O4 Synthesis, in Relation to Ferrite Plating. Journal de Physique IV Proceedings, 1997, 07 (C1), pp.C1-655-C1-657. 10.1051/jp4:19971269 jpa00254980

\section{HAL Id: jpa-00254980 https://hal.science/jpa-00254980}

Submitted on 1 Jan 1997

HAL is a multi-disciplinary open access archive for the deposit and dissemination of scientific research documents, whether they are published or not. The documents may come from teaching and research institutions in France or abroad, or from public or private research centers.
L'archive ouverte pluridisciplinaire HAL, est destinée au dépôt et à la diffusion de documents scientifiques de niveau recherche, publiés ou non, émanant des établissements d'enseignement et de recherche français ou étrangers, des laboratoires publics ou privés. 


\title{
Mechanism of Biological $\mathrm{Fe}_{3} \mathrm{O}_{4}$ Synthesis, in Relation to Ferrite Plating
}

\author{
M. Abe and Y. Tamaura*. \\ Department of Physical Electronics, Tokyo Institute of Technology, O-okayama, Meguro-ku, Tokyo, 152, \\ Japan \\ * Research Center for Carbon Recycling and Utilization, O-okayama, Meguro-ku, Tokyo, 152, Japan
}

\begin{abstract}
The mechanism of the magnetosome $\left(\mathrm{Fe}_{3} \mathrm{O}_{4}\right)$ formations is elucidated from the basic findings on chemical reactions of iron oxides, especially those occurring in ferrite plating-a chemical process synthesizing spinel ferrite films from an aqueous solution. It is suggested that in both the biomineralization and the ferrite plating, (1) $\mathrm{Fe}^{2+} \rightarrow \mathrm{Fe}^{3+}$ oxidation by $\mathrm{NaNO}_{2}$ plays an essential role, (2) $\gamma-\mathrm{FeOOH}$ is formed as a precursor, and (3) $\mathrm{Fe}^{2+}$ ions are adsorbed on $\gamma-\mathrm{FeOOH}$ which is followed by spinel formation. It is also discussed how to synthesize ferrite films at room temperature by mimicking the biological $\mathrm{Fe}_{3} \mathrm{O}_{4}$ formation.
\end{abstract}

\section{INTRODUCTION}

Magnetite $\left(\mathrm{Fe}_{3} \mathrm{O}_{4}\right)$ is the only known biogenic materials exhibiting ferromagnetism, which is found in fossil records and living organisms of various creatures [1]. Among the $\mathrm{Fe}_{3} \mathrm{O}_{4}$ biomineralizations, magnetosomes (which magnetotactic bacteria synthesize to use as a compus) has been attracting most intensive interest. The magnetosomes are $\mathrm{Fe}_{3} \mathrm{O}_{4}$ single crystals encapsulated by a membrane of lipid bilayer. Mann et al. [2] proposed that the $\mathrm{Fe}_{3} \mathrm{O}_{4}$ crystals are synthesized in the vesicles of the lipid bilayer, which involves the following steps: (1) uptake of $\mathrm{Fe}^{3+}$ ions from the environment into within the magnetsome vesicles by reduction step transforming $\mathrm{Fe}^{3+}$ to $\mathrm{Fe}^{2+},(2)$ precipitation of hydrated ferric oxide within the vesicles, and (3) transformation of the hydrated ferric oxides to $\mathrm{Fe}_{3} \mathrm{O}_{4}$.

In order to further elucidate the mechanism of the biological $\mathrm{Fe}_{3} \mathrm{O}_{4}$ formation, we will examine in this paper the basic findings on chemical reactions of iron oxides, especially those occurring in ferrite plating - a chemical process synthesizing spinel ferrite films from an aqueous solution $[3,4]$. We will also discuss how to synthesize ferrite films at room temperature by mimicking the biological $\mathrm{Fe}_{3} \mathrm{O}_{4}$ formation.

\section{BIOMINERALIZATION AND FERRITE PLATING}

A close reaction has been found between the biomineralization and the ferrite plating as follows.

[1] In vitro experiments using an enzyme, cytochrome $\mathrm{cd}_{1}$, extracted from magnetotactic bacteria suggested that the magnetite is synthesized from an aqueous solution of $\mathrm{Fe}^{2+}$ via oxidation of $\mathrm{Fe}^{2+}$ to $\mathrm{Fe}^{3+}$ by $\mathrm{NaNO}_{2}$ activated by the enzyme [5]. The $\mathrm{Fe}^{2+} \rightarrow \mathrm{Fe}^{3+}$ oxidation plays an essential role also in the ferrite plating, for which $\mathrm{NaNO}_{2}$ has been found to be the most expedient oxidizing reagent $[3,4]$.

[2] In the biological formation of $\mathrm{Fe}_{3} \mathrm{O}_{4}$ found in the denticles of the radular teeth of chiton, a shellfish, the $\mathrm{Fe}_{3} \mathrm{O}_{4}$ coating is formed, as shown in Fig.1, on apatite intermediated by $\gamma-\mathrm{FeOOH}$, a ferric hydroxy oxide [6,7]. This suggests that $\gamma$ $\mathrm{FeOOH}$ is found as a precursor on which $\mathrm{Fe}_{3} \mathrm{O}_{4}$ is produced. In the ferrite plating similar event is thought to occur, as inferred from the following experimental results.

When an aqueous solution $(\mathrm{pH}=8.5)$ of $\mathrm{Fe}^{2+}$ ions, or $\mathrm{Fe}(\mathrm{OH})_{2}$, was added continually to the aqueous solution ( $\mathrm{pH}$ $=8.5$ ) suspending fine particles of $\gamma-\mathrm{FeOOH}$, the amount of $\gamma-\mathrm{FeOOH}$ reduced, while that $\mathrm{Fe}_{3} \mathrm{O}_{4}$ increased, as analyzed by $\mathrm{X}$-ray and chemical analyses (Fig.2) [8]. When $\mathrm{Fe}^{2+}$ ions were added to an aqueous solution $(\mathrm{pH}=8.5)$ in which a stainless steel plate with a $\gamma$ - $\mathrm{FeOOH}$ coat on the surface was immersed, $\mathrm{Fe}_{3} \mathrm{O}_{4}$ was formed on the $\gamma-\mathrm{FeOOH}$ layer as directly shown by an electrochemical method (Fig. 3) [9]. 


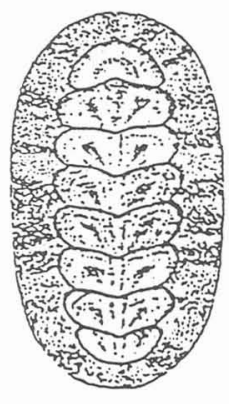

(a)

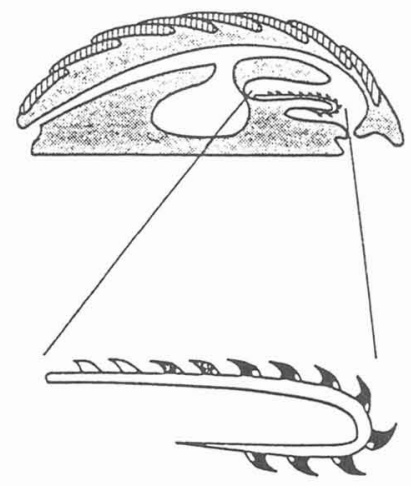

(b)

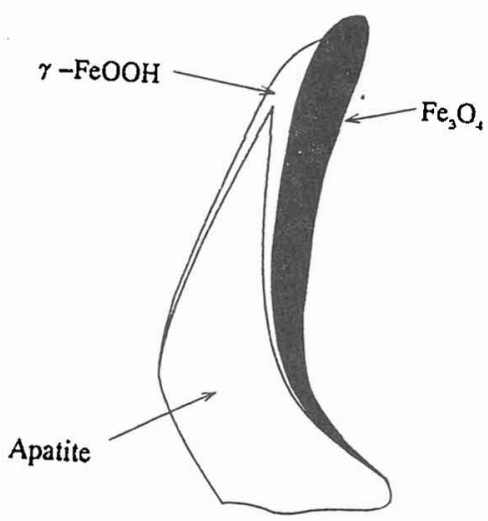

(c)

Fig. 1 (a): dorsal of chiton [7] , (b): cross sections of chiton and its radula having denticles. (c): cross section of denticle [6] .

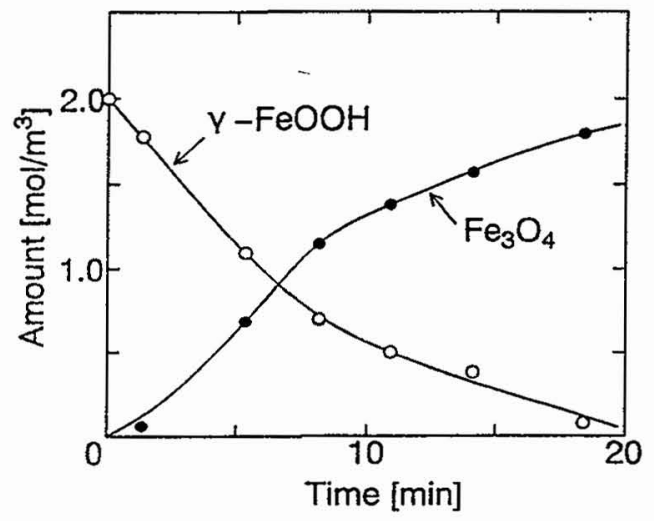

Fig. 2 Amount of $\gamma$-FcOOH (open circles) and $\mathrm{Fe}_{3} \mathrm{O}_{4}$ (closed circles), plotted as a function of time [8].

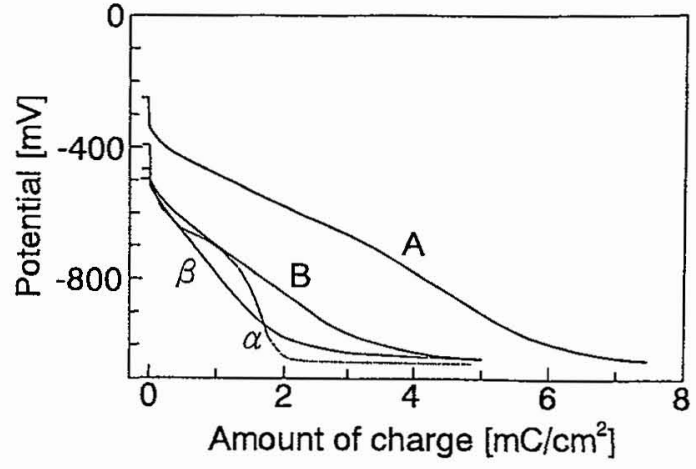

Fig. 3 Cathodic reduction curves obtained for oxide layers, $\mathrm{A}: \mathrm{Fe}^{2+}$ ions were adsorbed on substrate surface which were then oxidized by air; $\mathrm{B}: \mathrm{Fe}^{2+}$ ions were adsorbed again on the layer $\mathrm{A} ; \alpha: \gamma-\mathrm{FeOOH}$ layer; and $\beta: \mathrm{Fe}_{3} \mathrm{O}_{4}$ layer. A has an inflection point around $660 \mathrm{mV}$, which coincides with that observed for $\alpha$, showing that the layer $\mathrm{A}$ is $\gamma-\mathrm{FeOOH}$; while $\mathrm{B}$ has no inflection point similar as $\beta$, thus revealing that the layer $\mathrm{B}$ is $\mathrm{Fe}_{3} \mathrm{O}_{4}[9]$. 


\section{ROOM TEMPERATURE $\mathrm{Fe}_{3} \mathrm{O}_{4}$ SYNTHESIS MIMICKING BIOMINERALIZATION}

The ferrite plating is enabled only at high temperature, above $\sim 60^{\circ} \mathrm{C}$, while the biological $\mathrm{Fe}_{3} \mathrm{O}_{4}$ formation is realized at room temperature. How to realize ferrite plating with reasonable speed of film deposition at room temperature?

As shown in the previous section, the formation of $\mathrm{Fe}_{3} \mathrm{O}_{4}$ from the $\mathrm{Fe}^{2+}$ aqueous solution have two major steps, (1) oxidation of $\mathrm{Fe}^{2+}$ to $\mathrm{Fe}^{3+}$, forming the precursor, or $\gamma-\mathrm{FeOOH}$; and (2) adsorption of $\mathrm{Fe}^{2+}$ on $\gamma-\mathrm{FeOOH}$ which accompanies the spinel formation. When temperature is decreased from $\sim 60 \sim 100^{\circ} \mathrm{C}$ to room temperature, the rate of the spinel formation decreases much, while the rate of the $\mathrm{Fe}^{2+}$ oxidation decreases moderately. Therefore, the $\mathrm{Fe}^{2+} \rightarrow \mathrm{Fe}^{3+}$ oxidation overwhelms the $\mathrm{Fe}^{2+}$ adsorption accompanying the spinel formation, so that not $\mathrm{Fe}_{3} \mathrm{O}_{4}$ but ferrous compounds such as $\gamma-\mathrm{FeOOH}$ and $\alpha-\mathrm{Fe}_{2} \mathrm{O}_{3}$ are formed at room temperature from the aqueous $\mathrm{Fe}^{2+}$ solution, as long as the conditions other than the temperature are unchanged in the ferrite plating. When the speed of the oxidation is reduced by someway, e.g. using very dilute air $/ \mathrm{N}_{2}$ mixed gas as the oxidizing reagent, $\mathrm{Fe}_{3} \mathrm{O}_{4}$ has been actually synthesized at room temperature, though the growth rate is very low $[10]$. Therefore, we must stimulate the spinel formation in order to realize room temperature ferrite plating of reasonable speed. This may be attained by using substrates with functionalized surface [11], as of lipid bilayer of vesicles [12] or cast films [13], and of Langmuir-Blodgett films, which mimick the magnetosome membrane. It may be also attained by utilizing enzymes which the magnetotactic bacteria use to stimulate the spinel formation.

\section{ACKNOWLEDGMENTS}

The authors are indebted to Prof. Y. Fukumori, Dept. of Life Science, Tokyo Institute of Technology, for fruitful discussion.

\section{References}

[1] J. L. Kirschvink, Bioelectromagnetics, 10 (1989) 239-259.

[2] S. Mann, N.H.C. Speaks and R. Board, Adv. Microb. Physiol. 31 (1991) 125-181.

[3] M. Abe, Ferrites: Proc. Int. Con. Ferrites (ICF 6), Tokyo and Kyoto, Japan, 1992, Jpn. Soc. Powder Powder Metal., pp. 472-477.

[4] M. Abe, T. Itoh and Y. Tamaura, Thin Solid Films, 216 (1992) 155-161.

[5] T. Yamazaki, H. Oyanagi, T. Fujiwara and Y. Fukumori, Eur. J. Biochem. 233 (1995) 665-671.

[6] H. A. Lowenstam, Science, 156 (1967) 1373-1375.

[7] Y. Maeda and M. Mizota, Kotai Butsuri ( Solid State Physics) 19 (1984) 52-60 [in Japanese] .

[8] Y. Tamaura, M. Saturno, K. Yamada and T. Katsura, Bull. Chem. Soc. Jpn. 57 (1984) 2417-2421.

[9] Y. Tamaura, Y. Kobori and T. Katsura, Nippon Kagaku Kaishi ( J. Chem. Soc. Jpn.) 10 (1983) 1433-1436 [in apanese]

[10]Y. Tamaura, Adv. Ceramics 15 (1986) 87-92.

[11]B. C. Bunker, P. C. Rieke, B. J. Tarasevich, A. A. Campbell, G. E. Fryxell, G. L. Graff, L. Song, J. Liu, J. W. Virden and G. L. Mcvay, Science 264 (1994) 48-55.

[12]S. Mann, D. D. Archibald, J. M. Didymus, T. Douglas, B. R. Heywood, F. C. Meldrum and N. J. Reeves, Science 261 (1993) 1286-1292.

[13]H. Okada, K. Sakata and T. Kunitake, Chem. Mater. 2 (1990) 89-91. 